\title{
DUAL BANKING SYSTEM PASKA MERGER DI INDONESIA
}

\author{
Arivatu Ni'mati Rahmatika*1 \\ ${ }^{1}$ Ekonomi Syariah \\ Universitas KH. A. Wahab Hasbullah Jombang \\ Email: arivaturahmatika@unwaha.ac.id \\ Nurvita Putri Romadhani ${ }^{2}$ \\ ${ }^{2}$ Ekonomi Syariah \\ Universitas KH. A. Wahab Hasbullah Jombang \\ Email: nurvitaputriromadhani@gmail.com
}

\begin{abstract}
This article explains that (1) The Post-Merger Dual Banking System is banking that has been implemented in Indonesia. Management of assets along with third party funds with large revenues that have been obtained from conventional banks and Islamic banks, third party funds that run in accordance with funding and lending. Conventional banks and Islamic banks provide credit financing to MSMEs (Micro, Small and Medium Enterprises) and differentiate in operations between conventional banks and Islamic banks, (2) this study aims to determine the concept of differences in the management and distribution of funds in the dual banking system in Indonesia before and after the merger, (3) the method used is a qualitative method in the form of a library (library research), (4) The results of the research are the post-merger dual banking system still manages and distributes MSME credit/financing funds to the public.
\end{abstract}

Keywords: Merger, Dual Banking system, Assets, Third Party Funds (DPK), Distribution of Funds.

\begin{abstract}
Abstrak
Jurnal ini menjelaskan (1) Dual Banking System Paska Merger ialah perbankan yang telah diterapkan di Indonesia. Pengelolaan aset bersamaan dana pihak ketiga yang pendapatannya besar yang telah didapatkan pada bank konvensional dan bank syariah, dana pihak ketiga yang berjalan sesuai dengan funding dan lending. Bank konvensional dan bank syariah memberikan pembiayaan dana kredit terhadap UMKM (Usaha Mikro Kecil Menengah) dan membedakan dalam operasional antara bank konvensional dan bank syariah, (2) penelitian ini bertujuan untuk mengetahui konsep perbedaan pengelolaan dan penyaluran dana pada dual banking system di Indonesia sebelum dan sesudah merger, (3) metode yang digunakan dengan metode kualitatif yang berbentuk pustaka (library research), (4) Hasil penelitian bahwa antara dual banking system paska merger tetap mengelolah dan penyaluran dana kredit/pembiayaan UMKM pada masyarakat.
\end{abstract}

Kata kunci: Merger, Dual Banking system, Asset, DPK, Penyaluran Dana. 


\section{A. PENDAHULUAN}

Bank sebagai lembaga yang intermediasi yang melaksanakan tiga fungsi yaitu menerima simpanan uang, meminjam uang dan memberikan jasa pengiriman uang. ${ }^{1}$ Dual banking system mulai berlaku di Indonesia sejak berdirinya Undang-undang Nomor 10 Tahun 1998 tentang perbankan telah menjelaskan di Indonesia memiliki dual system (Dual Banking System) adalah perbankan syariah dan perbankan konvensional.

Merger merupakan gabungan dari dua atau lebih perusahaan untuk membentuk perusahaan baru. Merger melakukan secara internal maupun secara eksternal. Merger internal terjadi saat perusahaan sasaran berada dalam kepemilikan grup yang sama, sedangkan meger external terjadi ketika perusahaan target berada dalam grup yang berbeda dalam kelompok kepemilikan. $^{2}$

Pada saat ini masyarakat sangat mengenal antar bank konvensional dan bank syariah. Bank konvensioal adalah bank yang melaksanakan kegiatanya yang sesuai dengan konvensional. Sedangkan bank syariah ialah bank yang menjalankan kegiatan yang sesuai dengan prinsip syariah atau prinsip hukum islamnya yang sudah disepati.

\footnotetext{
${ }^{1}$ Ramdansyah Fitrah, "Menelirik Mekanisme Pembentukan Bank Umum Syariah Di Indonesia," Jurnal As-Salam 1, no. 3 (2017): 106-118.

2 Saefudin Zuhri et al., "The Impact of Merger and Acquisition on Financial Performance in Indonesia," Journal of Reseacrh in Business, Economics, and Education 2, no. 1 (2020): 326-338.
} 
Pengembagan sistem perbankan syariah di Indonesia dilakukan dalam kerangka dual banking system atau sistem perbankan ganda dalam kerangka arsutektur perbankan Indonesia, untuk menghadirkan alternatif jasa perbankan yang semakin lengkap kepada masyarakat Indonesia. Secara bersama, sistem perbankan konvensional dan perbankan syariah secara sinergis mendukung mobilisasi dana masyarakat secara lebih luas untuk meningkatkan kemampuan pembiayaan bagi sektor-sektor perekonomian nasional. ${ }^{3}$

Dual banking system melakukan dua sekaligus kegiatan, yaitu berbasis bunga dan berbasis syariah. Untuk yang mengubah bank mejadi bank syariah, mekaisme kerjanya mengikuti sesuai dengan prinsip-prinsip perbankan syariah, sedangkan bagi yang menjalankan kedua tugas tersebut sekaligus diatur mekanisme kerjanya, terutama dalam kegiatan yang berbasis bunga dalam hal interaksi ini adalah fitur unik dari perbankan syariah sehingga bank syariah dan bank ko nvensional dapat dipisahkan. ${ }^{4}$

Dual banking system tidak dapat beroperasi hanya menggunakan undang-undang nomor 10 tahun 1998 tentang perbankan karena dalam undangundang tersebut tidak ada ketentuan mengenai sistem bagi hasil seperti yang diemban oleh bank syariah. Sementara itu penerepan dual banking system pada bank konvensional tidak dapat beroperasi hanya undang-undang nomor 21 tahun 2008 tentang perbankan syariah karena dual banking system tidak menghapus

${ }^{3}$ www.ojk.go.id

4 Arivatu Ni'mati Rahmatika, "Dual Banking System Di Indonesia," At-Tahdzib: Jurnal Studi Islam dan Muamalah 2, no. 2 (2014): 133-147. 
Arivatu Ni'mati Rahmatika, Nurvita Putri Romadhani.

bunga ribawi. Dual banking system bukan sistem perbankan yang murni syariah seperti bank muamalah tetapi masih ada karakter bank konvensional pada umumnya.

Aset atau aktiva merupakan sember ekonomi atau suatu ilai kekayaan suatu entitas tertentu dengan harapan memberikan manfaat ekonomi dan sosial yang dapat diukur dalam satuan uang. ${ }^{5}$ Dana pihak ketiga Menurut Undangundang Perbankan Nomor 10 Tahun 1998 adalah simpanan dana yang dipercaya oleh masyarakat pada bank yang berdasarkan perjanjian penyimpanan dana dalam bentuk giro, deposito dan tabungan. Dana pihak ketiga beroperasional bank yang terpenting dana untuk masyarakat.

Dana pihak ketiga Menurut Undang-undang Perbankan Nomor 10 Tahun 1998 adalah simpanan dana yang dipercaya oleh masyarakat pada bank yang berdasarkan perjanjian penyimpanan dana dalam bentuk giro, deposito dan tabungan. Dana pihak ketiga beroperasional bank yang terpentig dana untuk masyarakat.

Menurut Undang-undang Perbankan No. 10 Tahun 1998 pembiayaan yang menurut prinsip syariah merupakan menyediaan uang ataupun tagihan yang dipersamakan dengan berdasarkan pada persetujuan atau kesepakatan antara bank dengan pihak lain yang mewajibkan pihak yang telah dibiayai untuk

\footnotetext{
${ }^{5}$ Sri Wahyuni \& Rifki Khoirudin, Pengantar Manajemen Aset ( Makassar : Nas Media Pustaka,2020), 123.
} 
mengembalikan uang ataupun tagihan tersebut setelah jangka waktu yang telah di tentukan dengan imbalan ataupun untuk bagi hasil.

Berdasarkan berbagai uraian di atas, bank Indonesia saai ini merupakan lembaga yang berwenang sebagai bank. Sejak diberlakukannya dual banking system bank di Indonesia telah ditegaskan melalui Undang-undang Nomor 10 Tahun 1998 dan Undang-undang Nomor 21 Tahun 2008 menghadirkan perbankan syariah di Indonesia. Telah menyatakan bahwa perbankan di Indonesia memiliki sistem (Dual Banking System) adalah perbankan syariah dan perbankan konvensional. Oleh karna itu, ini akan membahas tentang bagaimana konsep pengelolaan dan penyaluran dana pada bank konvensional dan bank syariah sebelum dan sesudah merger dengan sistem dual banking system yang ada di Indonesia.

\section{B. METODE PENELITIAN}

Metode penelitian yang digunakan adalah metode kualitatif yang berbentuk kepustakaan (library research). Jenis data yang digunakan data sekunder data yang didapatkan berasal dari penelitian terdahulu, melalui kepustakaan dan dari media seperti, jurnal, skripsi, berita dan internet lainnya yang berhubungan dengan pembahasan. ${ }^{6}$

Pembahasan penelitian fokus terhadap membandingkan sebelum merger dan pasca merger dalam pemberian penyaluran dana kredit/pembiayaan UMKM

6 Sugiyono. Metode Penelitian Kuantitatif, Kualitatif Dan RED. Edited by IKAPI. (Bandung: Alfabeta, 2016), 17. 
Arivatu Ni'mati Rahmatika, Nurvita Putri Romadhani.

(Usaha Mikro Kecil dan Menengah) pada bank konvensional dan bank syariah. Tujuan penelitian adalah untuk memperjelas perbandingan sistem pengelolaan dan penyaluran dana pada dual banking system sehingga keduanya dapat dibedakan.

Penulisan pembahasan ini menggunakan prosedur mencari informasi yang mengenai pembahasan, yang berupa penelitian terdahulu, kemudian menalaah dan menganalisis berbagai sumber yang berhubungan dengan pembahasan yag di angkat oleh penulis.

\section{HASIL PENELITIAN}

\section{Sistem Sebelum Merger}

Dalam penelitian sebelumnya dual banking system di indonesia. Menjelaskan bahwa Dual banking system bank yang melaksanakan dua kegiatan ialah bank konvensional serta bank syariah. Bank yang beroperasi secara konvensional pemasukan paling utama dari bunga yang telah di hitung pada prosentase dari pinjaman yang dipinjam oleh nasabah yang sudah diberikan dari pihak bank. Sedangkan, bank yang beroperasi secara syariah pendapatannya dari pembagian laba yang dihitung antara pinjaman yang diberikan bank dengan modal keseluruhan yang dipunyai perusahaan kepada nasabah pembiayaan/kredit. Hasil usaha dibagi sesuai dengan kesepakatan pada saat waktu akad pembiayaan yang sudah disepakati antara bank dan nasabah yang 
telah ditulis dalam bentuk nisbah. Sama dengan bank konvensional, bank yang melakukan secara prinsip syariah memiliki kewajiban memberikan imbalan untuk penyimpan dana dalam wujud bagi hasil terhadap jumlah masing-masing jenis simpanan.

Kemudian pada penghimpunan dana pihak ketiga yakni sumber dana terbanyak, bank menaruh serta memutarkan uang setelah itu ditarik lagi kala jatuh tempo dengan berbentuk bunga. Pengembangan kredit bersangkutan dengan bank serta kredit berguna untuk bank karena memiliki sumber pemasukan yang besar. Perbankan sediakan modal untuk usaha sehingga berkembang lebih cepat, kredit jenis yang harus yakni kredit usaha kecil yang bertabiat obligation dari bank kepada masyarakat.

Dalam pengelolaan aset dual banking system memiliki manajemen tunggal di bank indonesia. Yang mana antara bank konvensional dan bank syariah senantiasa memikirkan metode supaya dana yang menumpuk tidak nganggur. Pada pengelolaan aset bersamaan dengan dana pihak ketiga (DPK), pengelolaan aset yang di maksud dengan penyaluran dana yang diserahkan pada tiap-tiap lembaga keuangan kemudian penyaluran dana digunakan kepada UMKM (Usaha Mikro Kecil Menengah) disebabkan sangat memerlukan dorongan dana.

\section{Sistem Pasca Merger}




\section{Arivatu Ni'mati Rahmatika, Nurvita Putri Romadhani.}

Undang-undang pemerintah indonesia No 21 Tahun 2008 perbankan syariah menyimpulkan kalau indonesia menerapkan sistem bank ganda atau yang di sebut dual banking system yaitu bank konvensional serta bank syariah. Bank syariah ialah badan usaha sektor keuangan yang melaksanakan kegiatan usaha yang bersumber pada syariah. Hukum perbankan syariah pula telah mengharuskan bank syariah untuk menjalankan fungsi sosial semacam lembaga baitul maal, yaitu menghimpun dana dari sedekah, wakaf dan zakat?7.

Tren industri perbankan syariah di indonesia terus menjadi bertambah, bersumber pada laporan state of the global islamic ekonomi report (GIER) pada tahun 2019-2020, indonesia terletak di posisi ke 4 dari Top 15 Global Islamic Economy Indicator Score Rank by Sector. Yang sesuai perkembangan hingga tahun 2021 sektor perbankan syariah menurut laporan statistik perbankan syariah dari Otoritas Perbankan Syariah (OJK) tahun 2021 yang terdiri dari 12 bank umum syariah, 20unit usaha syariah, 163 bank pembiayaan rakyat syariah dengan market share per Desember 2020 sebesar 9,89\% untuk sektor keuangan syariah. Kementrian badan usaha milik negara (BUMN) yang telah membentuk merger tiga bank syariah yaitu Bank Syariah (BRIS), Bank Syariah Mandiri (BSM) serta Bank BNI Syariah (BNIS). Hasil merger dari 3 bank syariah menciptakan PT Bank

${ }^{7}$ M. fikri Himmawan, "Merger Bank Syariah Indonesia" https://retizen.republika.co.id/posts/10920/merger-bank-syariah-indonesia-bsi 
Syariah Indonesia yang mana saat ini merupakan bank yang terbesar di indonesia8.

Asset Liabbility Management (ALMA) pada bank syariah indonesia mewujudkan ekosistem keuangan syariah di indonesia. Pasca merger pada bank syariah indonesia merupakan faktor penentu yang sangat berarti, yang mana ketika terjadi akumulasi input yang optimal sehingga harus menghasilkan output yang maksimal pula sehingga efisiensi terjadi, industri perbankan syariah adalah salah satu industri unggulan di sektor keuangan syariah yang berperan antara pihak defisit dengan pihak surplus memiliki kepercayaan kepada bank. Fungsi intermediasi bank dapat memperkuat kekuatan ekonomi yang membentuk ekosistem keuangan syariah di indonesia, yang mana bank sebagai lembaga keuangan meningkatkan efisiensi operasional atau optimalisasi keuangan yang terkait dengan manajemen aset. Dana dari pihak ketiga akan dikumpulkan oleh pihak bank yang kemudian disalurkan kepada pihak yang mengalami defisit yang berupa kegiatan produktif. Kegiatan produktif yang akan menghasilkan output yang menyerap tenaga kerja yang berdampak meningkatkan pendapatan secara mikroekonomi ataupun makroekonomi.

Tabel 1. Perbandingan Dual Banking System Sebelum Dan Pasca Merger
Sebelum Merger
\begin{tabular}{|l|l|l|} 
No & \multicolumn{1}{|c|}{$\begin{array}{l}\text { Pasca Merger } \\
\text { Seran }\end{array}$} \\
\hline 1 & $\begin{array}{l}\text { Perbankan telah menyediakan } \\
\text { modal usaha kepada pelaku } \\
\text { Usaha Mikro Kecil Menengah } \\
(\text { UMKM). }\end{array}$ & $\begin{array}{l}\text { Perbankan syariah tetap menjalankan } \\
\text { fungsi nasional semacam } \\
\text { penghimpunan dana. }\end{array}$ \\
\hline
\end{tabular}

${ }^{8}$ Ibid. 


\section{Arivatu Ni'mati Rahmatika, Nurvita Putri Romadhani.}

\begin{tabular}{|l|l|l|}
\hline 2 & Pihak bank menyalurkan kredit & Lembaga keuangan meningkatkan \\
& dana kepada masyarakat UMKM. & $\begin{array}{l}\text { efiseon operasional keuangan aset. } \\
\text { Yang mana dana pihak ketiga akan } \\
\end{array}$ \\
& & $\begin{array}{l}\text { dikumpulkan oleh pihak bank dan } \\
\text { kemudian disalurkan kepada yang } \\
\text { mengalami defisit yang berkegiatan } \\
\end{array}$ \\
& & produktif. \\
\hline
\end{tabular}

Dari sebelum merger dan pasca merger tetap menjalankan penyaluran dana kredit \pembiayaan pada UMKM (usaha mikro kecil menengah) yang memiliki potensi penyaluran dana yang bagus kedepannya.

\section{PEMBAHASAN}

Bank sebagai fungsi lembaga intermediasi antara seseorang yang memiliki kelebihan dana dan yang membutuhkan dana. Bank syariah dan bank konvensional memiliki fungsi yang sama tetapi dalam operasioal bank syariah berjalan sesuai dengan prinsip syariah. Sistem keuangan syariah di indonesia menjadi salah satu sistem yang terbaik dan telah di akui secara internasional.

Berdasarkan hasil perbedaan antara sebelum merger dan pasca merger dari berbagai sumber bahwa penyaluran dana kredit UMKM pada bank konvensional dan bank syariah yang pertama, prosedur pengelolaan penyaluran dana kredit UMKM; kedua, debitur yang berhak menerima kredit dana UMKM

Penyaluran dana kredit bank konvensional dan bank syariah yang didapatkan dari beberapa sumber tentang perbankan, pengelolaan dan penyaluran dana kredit kepada UMKM pada bank konvensional dan bank syariah. Perbankan ditugaskan menyediakan modal dengan bentuk kredit. 
Adapun perbedaan antara penyaluran dana kredit bank konvensional dan bank syariah yang ada di indonesia, antara lain sebagai berikut:

1. Prinsip Penyaluran Dana Kredit

Bank konvensioanl menerapkan dalam bentuk pemberian dana kredit kepada: kredit investasi, kredit modal kerja, kredit perdagangan, kredit konsumtif dan kredit produktif, sedangkan prinsip pemberian penyaluran dana pada bank syariah: prinsip mudharabah, jual beli dan secara bagi hasil.

2. Keuntungan antara bank konvensional dan bank syariah yang didapatkan.

Bank konvensional memperoleh keuntungan dari tingkatnya suku bunga yang diresmikan terhadap debitur yang mengajukan kredit dengan terdapatnya beban bunga tersebut, hingga jumlah pembayaran kredit yang di ajukan kepada debitur jumlahnya lebih besar dibanding dengan jumlah pinjaman. Sedangkan keuntungan bank syariah diperoleh dari kesepakatan kepada kedua bela pihak, ialah pihak bank dan pihak debitur. Kesepakatan ini untuk antara pihak bank dan pihak debitur yang mana pada akhirnya baik adanya kerugian ataupun keuntungan hendak ditanggung bersama.

3. Jenis pemberian modal bentuk kredit yang telah diberikan pada bank.

Pada bank konvensional tidak menghalangi tipe pemberian kredit yang disalurkan kepada masyarakat baik tipe modal usaha ataupun kredit investasi. Sedangkan bank syariah pembiayaan penyaluran dana kredit kepada debitur bila 
Arivatu Ni'mati Rahmatika, Nurvita Putri Romadhani.

jelas serta tujuan penggunaanya. Kreteria usaha yang dibiayai bank syariah mewajibka usaha-usaha yag halal. Jika usaha semacam usaha alkihol ditatap lebih banyak madharatnya dari pada khasiatnya sehingga tidak dapat diberi dana oleh bank syariah.

\section{E. KESIMPULAN}

Dapat disimpulkan bahwa bank memiliki 3 fungsi kedudukan pertama, dengan menerima simpan uang para nasabah. Kedua, sebagai meminjam uang nasabah dan ketiga, memberikan jasa pengiriman uang. Pada Bank konvesional dan bank syariah cara kerjanya sama-sama bergerak untuk mendapatkan profit.

Sebelum merger Dual banking system sebagai konsep perbankan di indonesia. Bank syariah yang digunakan untuk masyarakat muslim di indonesia agar dalam keamanan syariah dari berbagai macam transaksi. Pengelolaan aset bersamaan dengan dana pihak ketiga (DPK) sehingga pengelolaan aset tidak macet, pengelolaan yang dimaksud dengan cara penyaluran dana dan penyaluran dana kepada UMKM (Usaha Mikro Kecil Menengah)

Setelah merger hasil merger dari 3 bank syariah yaitu Bank Syariah, Bank Mandiri Syariah dan Bank Bni Syariah menciptakan PT Bank Syariah Indonesia yang mana saat ini merupakan bank yang terbesar di indonesia. Yang mana juga Dana dari pihak surplus akan dikumpulkan oleh pihak bank yang kemudian disalurkan kepada pihak yang mengalami defisit yang berupa kegiatan produktif. Kegiatan produktif yang akan menghasilkan output yang menyerap tenaga kerja 
yang berdampak meningkatkan pendapatan secara mikroekonomi ataupun makroekonomi.

Dengan adanya dana pihak ketiga untuk penyaluran dana umkm kepada masyarakat yang sesuai dengan kebutuhan. Adapun Perbedaan Pemberian penyaluran dana kredit bank konvensional dan bank syariah ialah: pertama, prinsip pemberian penyaluran dana kredit. Kedua, keuntungan antara bank konvensional dan bank syariah yang didaptkan. Ketiga, jenis pemberian modal bentuk kredit yang telah diberikan pada bank.

\section{F. DAFTAR PUSTAKA}

Fitrah, Ramdansyah. "Menelirik Mekanisme Pembentukan Bank Umum Syariah Di Indonesia." Jurnal As-Salam 1, no. 3 (2017): 106-118.

M. Fikri Himmawan. "Merger Bank Syariah Indonesia" https://retizen.republika.co.id/posts/10920/merger-bank-syariahindonesia-bsi

Rahmatika, Arivatu Ni'mati. "Dual Banking System Di Indonesia." At-Tahdzib: Jurnal Studi Islam dan Muamalah 2, no. 2 (2014): 133-147.

Sugiyono. Metode Penelitian Kuantitatif, Kualitatif Dan RED. Edited by IKAPI. Bandung: Alfabeta, 2016.

Tyagita dan Noven "Apakah Bank Syariah Berbeda Dengan Bank Konvensional" Jurnal Ekonomi Syariah, Vol.6 No.6 (2019).

Undang-Undang Republik Indonesia Nomor 10 Tahun 1998 Tentang Perubahan Atas Undang-Undang Nomor 7 Tahun 1992 Tentang Perbankan.

Undang-undang Republik Indonesia Nomor 21 Tahun 2008 Tentang Perbankan Syariah.

Sri Wahyuni \& Rifki Khoirudin, Pengantar Manajemen Aset. Makassar : Nas Media Pustaka, 2020. 
Arivatu Ni'mati Rahmatika, Nurvita Putri Romadhani.

Zuhri, Saefudin, Mochammad Fahlevi, M.N. Abdi, Dasih Irma, and Sari Maemunah. "The Impact of Merger and Acquisition on Financial Performance in Indonesia." Journal of Reseacrh in Business, Economics, and Education 2, no. 1 (2020): 326-338. 